\title{
Childe Harold's Journey to the East and "Authenticity"
}

\author{
Seyed Mohammad Marandi ${ }^{1, *}$, Hossein Pirnajmuddin ${ }^{2, * *}$ \\ ${ }^{1}$ English Department, University of Tehran, Tehran, Iran \\ ${ }^{2}$ English Department, University of Isfahan, Isfahan, Iran \\ *,**E-mail address: mmarandi@ut.ac.ir , pirnajmuddin@fgn.ui.ac.ir
}

\begin{abstract}
This essay deals with the notion of orientalist discourse in Lord Byron's Childe Harold's Pilgrimage. Concentrating on the dialectical attitudes towards the 'Orient' in Byron's poem the writers try to show, through a contrapuntal textual analysis, how signs emerge of a somewhat stereotypical and often monolithic Orient. It is argued that the work's claim on the authenticity of the representations of the East is a subtle textual strategy. This seems to be true despite the existence of seemingly more favourable views towards 'Orientals', especially in the footnotes, compared to Turkish Tales. Central to the study is the idea that similar discursive practices also seem to influence most of Byron's critics, which include contemporary scholars who have conducted numerous forms of textual analysis through differing theoretical approaches.
\end{abstract}

Keywords: Lord Byron; Childe Harold's Pilgrimage; Romanticism; the Orient; orientalism; authenticity

\section{INTRODUCTION}

With regard to the 'East' Byron is more significant and interesting than most other writers of his age. Unlike his contemporary Orientalist rivals, he actually travelled to and experienced the Orient. Therefore, it is important to gauge the extent to which Byron's Orientalist preconceptions are able to survive contact with reality as well as the extent to which they are modified. It is important to understand the extent to which the "correctness" and "truthfulness" of his Oriental representations were deemed as important by the poet as well as how and why his writings on the Orient were and still are widely regarded as reliable among literary scholars and critics. The fact that even modern critics often take it for granted that his observations were and still are valid shows that his emphasis on reliability, along with his representations, fits in well with the dominant stereotypes and discursive practices of more contemporary Orientalism.

The influence of Orientalism on Byron apparently began before the age of ten. His reading of Rycant's History of the Turks had a huge impact on his imagination. Subsequently, he began reading any book available concerning the Orient. These books included the works of Mignant, D'Herbert, Sir William Jones as well as Sale's translation of the Holy Qur'an, Jonathon Scott's edition of The Arabian Nights, and travellers' work by the Baron de Tott and Lady Mary Wortly Montagu. Even more important was the influence of Beckford's Vathek. Byron "drew 
extensively and with acknowledgement on Beckford -- or more correctly on Henley's notes for the annotations to The Giaour" (Joseph 1964, 44).

Byron's notes to the Oriental tales reflect the importance he placed on them being seen as authentic representations of the East. This can be easily seen through his extensive use of footnotes, Oriental words and imagery, and his letters. In the case of The Giaour, for example, he takes great care to inform the reader that the poem is both precise and empirically verifiable. The same can be said about his other poems. In Childe Harold's Pilgrimage, for example, there are very extensive and informative footnotes that argue the poet's claim of authenticity. The importance to Byron of this aspect of his poetry can also be seen in a letter to Murray on The Bride of Abydos, where he states, "I don't care a lump of sugar for my poetry -- but for my costume and my correctness I will combat lustily" (Marchand 1974, 165). Perhaps the best example of his keenness on reliability, and his wish to be recognized as such, is evident in Byron's letter to the famous traveller Edward Daniel Clark:

You are one of ye very few who can pronounce how far my costume (to use an affected but excessive word) is correct [...] I am sure that I am anxious to have an observer's - particularly a famous observer's testimony on ye Fidelity of my manners and dresses - and as far as Memory and Oriental twist in my imagination has permitted. (Marchand 1974, 199)

Byron's attention to Oriental detail increases the influence of his work in certain aspects. While literature alone plays a major role in assessing the cultural mood of previous generations as well as that of the present, any text that is viewed as authentic by its author and more importantly by its critics can, relatively speaking, be potentially far more influential in the ideological sense than a similar text which makes no such claim. Such a text, and in this case an Orientalist text, is not only seen by readers to be of aesthetic value, but more importantly it also acts as a reliable source of information about unfamiliar peoples and lands. Of course, Orientalist literature that makes no such claim to authenticity mediates between the real and imaginary worlds and can often be seen as a form of latent Orientalism. As ideologies intersect and battle one another through language and signs, all literary texts must be viewed "as extremely fecund sites for such ideological interactions" (Loomba 1998, 70).

Under normal circumstances the dominant discursive practices in the real world make it quite difficult, if not sometimes nearly impossible, for most individuals to think far beyond their strongly bounded areas of social knowledge. Therefore, as texts are regularly exercises in power and control, they can help us to better understand the environment in which they were written as well as read. This applies to Byron as well as his contemporary critics and his audience. However, it can also apply to modern critics in the field of literature as well. One of the objectives of this essay is to examine the extent to which Byron's constructions of the Orient are faithful to 'truth' or 'reality', and the extent to which they are the products of dominant ideologies. It is equally important to see how in different eras critics react to these representations. These objectives must be pursued while keeping in mind the problems surrounding any argument concerning 'reliability' and 'truth'.

\section{DISCUSSION}

Richard Cardwell has claimed that Byron's Oriental setting is more plausible as it was to be a vehicle of examining political and social subjects (152-172). In other words, the Oriental 
setting is the perfect place to objectively portray the positive and negative aspects of European culture and ideology. In the poetry of Romanticism, according to Jerome McGann, "actual human issues [...] are resituated in a variety of idealized localities" and readers are apparently astute enough to recognize the difference between the events in the text and reality (McGann $1983,1)$. Although these arguments at a quick glance may seem to be both simple and true, a closer study of the literary texts under discussion reveals that this is not necessarily the case. Even if one accepts the claim that Oriental stereotypes merely operate as tropes in these poems, they are only meaningful in so far as they have acquired the status of a truism. Besides, no matter how abstract the Orient of a particular construction is, some sort of relationship between the representation and a real Oriental place must exist, otherwise, there would be no reason for it to be called or recognized as Oriental. More important, though, is the counter argument that these claims themselves justify the dehumanisation of the Orient. Such arguments imply that the Oriental can indeed be used as a tool to discuss conditions in the West, thus confirming the concept of the Oriental as the backward and unworthy 'Other' that can be used legitimately as a suitable medium to depict the worst traits existing in Western civilization.

Nevertheless, in the case of Byron where claims to precise authenticity are made, such arguments have little merit, especially as, to quote Tom Mole, Byron was very careful in cultivating a favourable image for himself (Mole 2007, 82). Even if Byron's sole intention was to portray the West in an objective setting, vivid, meaningful, and implicative representations of the Orient are produced throughout his works. Even if one goes further and claims that Byron is discussing the condition of a universal humanity, the response would still be that it is at the expense of the Orient.

In order to strengthen the belief that an authentic representation of the Orient had been produced, Byron made extensive usage of local colouring in the Turkish tales. The importance of this, for Byron, was not confined to his own works. He lauded this characteristic in the works of others, as can be seen in a letter to Moore regarding Lalla Rookh. Here he states, "You have caught the colours as if you had been in the rainbow, and the tone of the East is perfectly preserved" (Marchand 1974, 249-50). This simple sentence is significant for a number of other reasons. First of all it affirms Thomas Moore's representation of the Orient as being faithful to the original. This alone shows the extent to which Orientalist discourse relies on "institutions, traditions, conventions, agreed upon codes of understanding" rather than the Orient itself (Said 1980, 22). As we learn from Byron's statement, there is no major difference between the Orientalism of Moore and Byron, because it is Byron who has confirmed the authenticity of Moore's representation. Both have created authentic constructions of the Orient, although only one of them has actually been there. Hence, one must assume that, like Moore, Byron was conforming to the materials and points of view already existing in travel books and that his underlying assumptions are similar to those of other Orientalists. That is probably why there is no substantial difference in the eyes of Byron between the representations produced by Byron the traveller and Moore the library Orientalist as well as why he finds Moore's representations to be completely reliable. Perhaps, if the degree, to which Byron relied upon Knolles' General Histoire alone, is taken into consideration, one could better understand the extent to which his works were influenced by 'knowledge' obtained before travelling to the Orient. Harold Wiener shows that Knolles' work was crucial to his understanding of the East, the Turk, and Islam (Wiener 1938, 78-81). This is just one example confirming the amount of ideological baggage Byron carried with himself to the Orient. Therefore, it could be claimed that Byron and Moore were both viewed as reliable, and were able to view one another as such, because they both followed similar ideologies, or in other words, because they worked and lived within similar discursive practices. 
Another important point revealed in Byron's letter to Moore is that Byron views himself as an authority on the East. His letter implies that he has been in the "rainbow". Hence, as an expert Orientalist he can pass judgment on the work of another. He can describe the East, make it speak, and render its mysteries plain to the West. This enhances the significance of his work, because one who has actually been inside the mysterious and exotic rainbow, has written them. According to Anne Fleming, the popularity of his works were actually linked to the fact that people in "civilized" Britain were "fascinated at the wild scenes the young nobleman had experienced in the land of the wild Albanian" (Fleming 1999, 100).

This simple statement also reveals the extent to which Byron generalized his limited personal knowledge about the East. In spite of the fact that he neither understood any of the languages of the Orient (such as Kurdish, Turkish, Arabic or Persian among numerous others), nor saw more than a small part of the Ottoman Empire for a brief period, Byron saw himself in a commanding position to understand and judge everything East and South of Europe. Moore's Lalla Rookh has little if anything to do with Byron's personal experiences. Its settings are in lands with languages, cultures, and religious sects that were very different from anything Byron had ever seen or experienced. Even the climate and landscape of these regions differ significantly from the areas that he visited. Yet Byron still saw himself as an authority over all these parts of the world. Clearly, he and his literary critics must have viewed the Orient as being relatively monolithic in order to have been able to make or back such claims.

Complex issues that arise from an apparently innocent statement made in a letter to a friend, reveal how Byron's works were influenced by, and were a part of, a complex discourse, which still exercises strong influences today. A discourse, which in the words of Said, "depends for its strategy on the flexible positional superiority, which puts the Westerner in a whole series of possible relationships with the Orient without ever losing him the relative upper hand" (Said 1980,12 ). The same is true for a large number of Byron's contemporaries as well as his much more recent critics. Byron's contemporaries largely praised his fidelity to the "Oriental costume" (Edinburgh Review 21:42). They were satisfied that the foreign words, images, and Oriental characters used in the poetry and the footnotes conformed to, or at least did not deeply conflict with, the existing and recognizable stereotypes of the Orient. This can be clearly viewed in the criticism of Francis Jeffrey:

In selecting subjects and characters for this purpose it was not only natural, but in great measure necessary to go back to the only age when strong passions were indulged, or at least displayed without controul [...] The savages and barbarians that are still to be found in the world, are, no doubt, very exact likeness of those whom civilization has driven out [...] The noble author has been obliged [...] to go out of his own age and country in quest of the same indispensable ingredients; and his lot has fallen among the Turks and Arabs of the Mediterranean: -- ruffians and desperadoes, certainly not much more amiable in themselves than the worst subjects of the others, -- but capable of great redemption in the hands of a poet of genius by being placed within the enchanted circle of ancient Greece and preserving among them so many vestiges of Roman pride and magnificence. (Rutherford 1961, 57)

Francis Jeffrey was very straightforward in his views about 'the Other'. However, it would be simple-mindedness to believe that his views are not in any way related to more current ideas regarding the East. The dominant discursive practices, it seems, have not significantly changed, although tactics, strategies, and language have. This is made evident when one sees 
contemporary critics acknowledging Byron's authenticity (or at least failing to refute it), ignoring his prejudices, or trivializing his racism. In many instances of more recent scholarship on Byron's Oriental poetry, it seems that most 'Western' or 'Westernised' critics and scholars view the poet's representations as more or less authentic. They often believe that the images of the East and Easterners portrayed in the poetry are accurate descriptions of Oriental life and the Oriental psyche. It is even regularly implied that such images actually reflect the reality of the Orient today. While these views are usually, but not always, expressed using more politically correct language than that used by Francis Jeffrey, they often reveal the belief that the East is essentially aberrant, irrational, backward, despotic, crude, inferior, and sexually corrupt. It is inferior to the England that he sometimes despises.

Lord Byron's rise to fame began with the publication of his first Oriental tale, Childe Harold's Pilgrimage. As soon as the first two cantos of this work were published in 1812, Byron immediately became famous. Perhaps one could even claim that he actually owes most of his fame to the Orient itself. Especially as the public and civilized Europe were so fascinated by the barbarity and cruelty supposedly predominant in the East and in the land of Ali Pasha. The immense popularity of this poem encouraged Byron to continue writing about the East.

Most of Byron's contemporary reviewers viewed Childe Harold's Pilgrimage as authentic. According to Keith Walker, at that time the poem was seen "as a descriptive poem of travel" and was praised for its accuracy (Walker 1979, 2-7). Byron's contemporaries took it for granted that his portrayal of the East was authentic. Whatever criticism that was directed at the poem, was not linked to this issue.

However, such an analysis of his representation of 'the Other' does not only come from Byron's contemporaries. Modern critics, who have also commented on the poem, see it as a reliable portrayal of Oriental life as well. This is implied in some texts while in others it is explicitly stated. Walker himself, for example, believes that in Childe Harold's Pilgrimage, Byron reveals a great deal of awareness about his contemporary world (5). According to Leslie Marchand, the poem "served as a picturesque travelogue for people who could not travel" (Marchand 1974, 217), while Muhammad Sharafuddin stresses the authenticity and realism of the poem's portrait of the Orient and Islam (Sharafuddin 1994, 243). The most striking claim about the first two cantos of the poem, perhaps, is made by Robert Gleckner who claims:

It is perhaps logical that $[\ldots]$ at the beginning of canto ii the poet should invoke Athena, the goddess of wisdom, as his muse; for he will tell no fairy tales nor gloss over reality but, seeing the world in all its factuality and truth, he will present us finally with the totality of its truth, the vision of the wise. (Gleckner 1967, 69)

This presentation of the "whole truth" is possible, in the words of Oueijan, because Byron was able to actually assimilate himself into Oriental culture (18). Regardless of the issue of validity, it is clear that discursive practices among Byron's contemporaries and modern day critics regarding Oriental representation are in many ways similar.

While the focus of this essay will be on attitudes towards Greece, Albania, and Turkey, Childe Harold's passage through the Spanish Peninsula must also be analysed, as it is both relevant and significant. The poetry and notes related to the journey through Portugal and Spain are linked to the larger question of Byron's Orientalism, because, as we shall see, he is perceived by critics to be journeying through what Caroline Franklin calls "the Moorish exoticism of Spain" (Franklin 2000, 59). 
In the first canto of the poem Byron speaks of the Portuguese with a great deal of contempt while his view of Spaniards is not accompanied with a great deal of respect either. What is significant to this study though, is how the people of the Spanish peninsula are in certain respects portrayed as similar to Orientals. According to the poem, Spaniards think more highly of exacting vengeance than of freedom itself. They actually seem to view revenge as a sort of virtue $(1,794-800)$. In this land friends can be conspired against under the slightest pretext. This is a quality that is also attributed to the Easterner throughout the Turkish tales as well as in the lines of Childe Harold's Pilgrimage $(2,657-60)$ as shall be seen. Even the footnotes affirm this claim. In the footnote to line 338 in canto 2 , there is an apparently authentic example of the Oriental's sense of vengeance and blood lust. Here Byron informs the reader of what he claims to be a personal experience of his own. He says that once, upon being merely pushed by an Englishman in Byron's service, his Muslim attendant, although emotionally attached to Byron, nearly stabbed "the dog" to death. Even after the affair ended, the reader is told, the Muslim "barbarian [...] never thoroughly forgave the thoughtless fellow who insulted him" (McGann 1983, 194).

All of these similar traits clearly establish a link between the Spanish-Portuguese character and the Orient. Although Byron's Spanish representations are on the whole more positive than their purely Oriental counterparts, the poet portrays them as savage, brutal, vengeful, and also full of vitality, qualities that are regularly attributed to Orientals. It is plausible to believe that Byron attributes these qualities to the Spanish because of their proximity to the Moors.

Through Calpe's straits survey the steepy shore;

Europe and Afric on each other gaze!

Lands of the dark-ey'd Maid and dusky Moor

Alike beheld beneath pale Hecate's blaze

$(2,190-93)$.

More importantly though is their Moorish background, which as Lopez points out, was brought about by "eight centuries of life shared with the Arabs" and "produced a cultural "crosscontamination" or "hybridisation" "of the Western and Eastern elements on the Peninsula" (Lopez-Baralt 1997, 1-2).

This explains why Prothero, for example, writes that the first two cantos of Childe Harold "opened the gates of the mysterious East", while the fact is that the first canto and part of the second canto has nothing to do with Albania, Greece, or Turkey.

Such an Oriental or Moorish influence is necessarily seen as barbaric and uncivilized if not evil in nature. In the words of Bagabas, "The remembrance of the Moorish Conquest of Spain creates a suffocating atmosphere" (164), an atmosphere, which is similar in nature to that of the Turkish occupation of Greece; the occupation of Western land by the barbaric Other.

It should be noted here that throughout his works Byron is consistent in his concern for the freedom of Europeans, despite his criticisms of their character and societies, whether they are British, Italian, or Greek. Rarely does he show such interest in people of other continents and religions. He also does not seem to show enormous concern for England's rise as a colonial power. Africa, India, and the Americas (i.e. the native Americans), apparently, do not need to "throw off the yoke of" the English or the Europeans. Even if Byron shows limited concern for some Western exploits, his overall themes of freedom and liberty are presented through a specifically Eurocentric perspective. 
The population of the Iberian Peninsula is seen as infected with Moorish blood and culture, but as stated they are not completely Moorish or Oriental in nature. Their European heritage, however defined, leaves open the possibility for at least partial redemption. Byron definitely sees signs of heroic resistance in Spain, and (to a lesser extent) in Portugal, which is linked to Greek resistance in that it is Western in essence. In one important way, however, there is a marked difference between the two. Spanish or Portuguese resistance to Napoleon is different from the struggle against the Moors or Turks in that it is not racial or religious. The language that the poet uses to describe the French is not comparable to that used to describe the Muslim. When Byron speaks of the French oppression of the Spanish, he does not use racial abuse. When describing Muslims, on the other hand, he continuously uses words such as "wild" $(2,514)$ and "savage" $(2,339)$ as racial descriptions. Even more revealing is the constant use of animal imagery throughout the Turkish tales when describing Orientals.

In his last lines on Spain the poet laments that for the foreseeable future the Iberian Peninsula will remain a prisoner of Napoleon and his fresh legions, which are pouring down the Pyrenees $(1,910)$. The narrator asks:

How many doubtful day shall sink in night,

Ere the Frank robber turn him from his spoil,

And Freedom's stranger-tree grow native of the soil! $(1,924-6)$.

The footnote to the last line $(1,926)$ explains that during the American and French revolutions, trees were often planted as symbols of "growing freedom" (McGann 1983, 282). American colonists, are praised on the one hand while on the other the poet fails to even recognize that this "growing freedom" in America came at the expense of native Americans who were continually being killed or forced to leave their lands from the start of European colonisation.

Eventually, the Spanish Peninsula is left behind and Childe Harold moves on into the land where "barbarism" takes its ultimate shape, the land of Ali Pasha. In Byron's description of the people and culture of this part of the world, once again literary critics see a display of authenticity and truth. According to Bagabas, the poet, "in his elaborate description of Ali and of Ionnina's court, captures the glamour and splendour of oriental life" (Bagabas 1993, 174). He then adds that it does not escape Byron's:

[...] attention that "the bearded Turk" with his arrogance, pride, haughtiness and feeling of superiority to others to the degree that he "rarely deigns to speak" $(2,58.8)$ are features that distinguish Turks from other nations [...]. The sultan's practice of surrounding himself with dumb men who communicated only with signs while "he will be understood by his looks" was found to be not only strange and humiliating to others but also satanic. (Bagabas 1993, 174)

While making these questionable remarks, Bagabas fails to realise that Ali Pasha is not a Turk and like Byron, the critic seems to see all Orientals as being more or less similar to one another. He implies that Oriental despots, like all Orientals, are essentially different from Westerners and Western rulers. Like the poet, this critic claims to have knowledge about the general behaviour of all Easterners, thus allowing him to compare Easterners to their European counterparts and acknowledging their inferiority and evilness. 
Upon entering this land "of savage men" $(2,339)$ which "many dread to view" $(2,382)$, Harold, "bade to Christian tongues a long adieu" $(2,380)$. From here onwards one sees that even the land becomes wilder and that the wildness of the land too is linked to the character of its inhabitants. "Here roams the wolf, the eagle whets his beak, / Birds, beasts of prey, and wilder men appear" $(2,376-77)$. The Oriental inhabitants are spoken of alongside wild animals of prey, thus implying a brutish essence. That is why in the East the "red" $(2,388)$ and bloodstained "cross descends, thy minarets arise" $(2,340)$. In a land where, in the words of Sharafuddin, "Islamic political tyranny" (256) dominates life, nothing less is expected. The secular Byron freely uses Christian symbols in order to further antagonize the Oriental Muslim and to portray Christians as being far more civilised than Muslims.

In this land where the Greek population is enslaved, the bearded Muslim despot rules and commits crimes beyond description. These negative qualities are not just a part of Ali Pasha's personality. "All the sons of the mountains" $(2,651)$ have such characteristics, as the Western "voice of Ruth" is unheard of among Orientals. Whether this is true or not, in the eyes of Byron, the Oriental has a completely different set of values and this is particularly made clear when compared to England where "free-born men" $(2,97)$ :

\section{$[\ldots]$ preserve}

that strict restraint, which broken, ever balks

Conquest and Fame: but Britons rarely swerve

From law, however stern, which tends their strength to nerve $(2,168-71)$.

In the East concepts such as freedom, law, and mercy are meaningless to the barbaric "dark" man.

Even though the Albanians "stretch'd the welcome hand" $(2,604)$ and warmly welcomed Childe Harold as their guest $(2,628)$, they are still viewed as savages, thus leaving a certain ambivalence in Byron's portraits of the East. Albanians are seen, in the eyes of McGann, as barbaric because they have no share in "the world's most noble values" which have their roots in Western civilisation (49). According to Byron, "butcher-work" $(2,603)$ is a ceaseless aspect of Eastern life and, of course, is not merely linked to the personality of Ali Pasha. In the words of McGann, the Pasha is the "prototype" (McGann 52) of these people, an argument which Blackstone backs in virtually the same terms (Blackstone 1974, 99). In the eyes of the poet, Muslims are all "warrior-men" $(2,494)$ who only seem to be capable of contemplating the "promise of war" $(2,690)$, bloodshed and bribery. To describe what Bagabas calls "Byron's evaluation of the Turkish people", the term "noble savage", which was widely used in the eighteenth century, is seen as quite suitable. This is because, Bagabas believes, "it epitomizes Byron's astonishment at finding such nobility in these savages" (178). Rutherford writes in similar terms about the nobility that can be found in the uncivilised Albanians (34). When Muslim hospitality is acknowledged, however, Byron explains that this hospitality only exists because the "Mussulmans have been beaten into a kind of sullen civility, very comfortable to voyagers" (McGann 1983, 209). This nobility does not make them in anyway similar or comparable to civilised Europeans, of course. Indeed, far from being portrayed as civilised, according to Blackstone, in the second canto Byron actually succeeds in "conveying the austere ferocity of Islam" (1974, 88-89).

Although Byron states that Albanians "loathe alike the Frank and Turk" $(2,602)$, they and the Turks are portrayed in the same light throughout the second canto, as is more or less the case throughout all the Eastern tales. In Byron's view being Albanian or Turkish is almost 
the same thing, as they both represent a single and monolithic entity: the ferocious 'Other'. They are constantly inter-exchanged and the reader sees little distinction between the two in the work. The "scourge of the Turkish hand" $(2,709)$ is indistinguishable from that of the "wild Albanian" (2, 514).

The perception of an irrational, noble, and barbaric 'Other' is constantly strengthened by the authenticating footnotes accompanying the text. The footnote to line 338 of canto 2, where the poet writes of a Muslim "Dervish" who accompanied him during his travels in Albania serves as a good example. Once, when the poet was ill, this "barbarian", he claims, threatened to cut the throat of his physician if he was not quickly cured, yet the same Muslim nursed the ailing poet in a manner that "would have done honour to civilisation" (McGann 1983, 193). Byron also describes how this supposed "Dervish" who "was always squabbling with the husbands of Athens" continuously wept and lamented when it was time for Byron to depart. Nevertheless, the same person almost kills an Englishman because he was merely pushed (McGann 1983, 193-94). Even an Oriental who is on friendly terms with a "giaour", it seems, can not be redeemed from his barbaric vigour.

Like the qualities mentioned above, the extreme degree of Oriental despotism and extravagance is, according to the poem, more or less incomparable to anything that can be found in the West. Here $(2,500)$ and throughout $(2,570-76)$ the luxury, pomp, and despotism of the East is portrayed as excessivelike all other qualities that can be found in this part of the world. This belief is shared by Gleckner, who sees Byron's "spirited attack on bloody, tyrannical, immoral Turkey" $(1967,85)$ as "reasonable" $(1967,80)$. No proof is needed or presented to justify this claim. It seems unnecessary to prove that the East is less civilised than the West.

It also seems to be taken for granted by some that despotism is an essential characteristic of the monolithic Oriental in all ages and at all times. When Byron says, "The East -- ah, there it is" (Oueijan 1999, 17), it is implied that by passing a certain borderline the poet has entered a new and largely monolithic world. It seems that once the traveller has seen a part of Albania or Turkey, he has in fact seen all of the Middle East, North Africa, and South Asia to say the least. Hence, if he sees particular qualities in one man (Ali Pasha) or in his affiliates, he can conclude that all people of the East are as such. This assumption is true among many of his critics as well. As Blackstone puts it "the spider Ali" is not unique among his people (1974, 99). This type of character is normal in this part of the world. Ali Pasha:

[...] was not only a bloodthirsty tyrant but also a Baba of the Bektashi order of dervishes. Here power is 'lawless law' (xlvii), wisdom is 'the Muezzin's call' (lix), love is 'the shameless torch of wild desire' lit 'for boyish minions of unhallowed love' (in a cancelled stanza) [...] here passions are lived without concealment, without shame and without dilution; life and death hang on the lifting of an eyebrow, the folding of a turban, the cadence of a flattering phrase. It's hell for the Greeks of course [...]. (Blackstone 1974, 97)

These generalizations about entire races, nations, and communities are largely based on the general Western perceptions of 'the Other'. This is why Oueijan sees Blackstone's other work, Byron and Islam: the Triple Eros, which follows the same line of thought, as "the most illuminating and interesting of all the studies of Byron's Oriental reading" (Oueijan 1999, 19). It is also why Oueijan sees Ali Pasha as confirming "Byron's image of the powerful, passionate, and wise Eastern ruler" $(1999,40)$. The Pasha not only represents the Orient, he represents the best of it. 
According to the historian K.E. Fleming, the Pasha had a very different personality from what we come to understand through reading Byron and the literary critics. According to Fleming, Ali Pasha "was neither truly Muslim nor Ottoman, neither Oriental nor despotic" $(1999,23)$, while his relationship to the West as well as the East "was ambivalent and volatile" $(1999,81)$. He knew little if any Turkish and, although he was Albanian, "the tongue of his courtly business and correspondence was demotic Greek" (Fleming 1999, 24). He was fully aware that his Greek secretaries were members of a secret revolutionary cell working for Greek independence. In 1819 Ali Pasha also claimed to be a member of this organization as well, "in the hope of forging an alliance with the Greek revolutionaries against the Ottomans" (Fleming 1999, 31). Near the end of his rule he announced that he had converted to Christianity to gain Greek support (Fleming 1999, 68). While Ali Pasha is presented by Byron as a representative of Islamic civilisation, he was actually born in a family that had recently converted to Islam from Christianity and he was not really interested in religion (Fleming 1999, 23). Hence, according to Fleming:

[...] it seems clear that Ali was given to treating the Orthodox in a privileged fashion, as they were central to the trade of his region and thus to his personal prosperity [...]. $(1999,145)$

Fleming's work disproves Bagabas' claim that "in Byron's extended description of Ali Pasha's court, he relies heavily on factual personal experiences" $(1999,175)$. This is natural when one considers how brief Byron's visit was as well as how little he knew of the local culture and languages (besides some Greek). Fleming's work also casts doubt upon Sharafuddin's claim that the "authenticity" of the tales in general and Childe Harold's Pilgrimage in particular, presents a "new degree of reality to Islam as a form of life" and that here Islam "plays its full part as itself" (1999, 243).

According to Sharafuddin in Byron's:

[...] encounter with Ali Pasha, described in Childe Harold, canto II, [...] the virtues that come from absolutism -- dignity, confidence, generosity, courage -- are appreciated and indeed extolled. $(1994,250)$

This is not an isolated case. Blackstone too suggests that Ali Pasha is portrayed in a positive light, and "even better" in the letters that Byron wrote to his friends and family at about the same time as Childe Harold's Pilgrimage (1974, 95).

Regardless of the character of Ali Pasha, and whether he is truly a legitimate representation of an Oriental Muslim, critics often show a sense of indisposition towards Muslims and their expectations of Orientals are very low. What would normally be seen as derogatory language seems to them words of praise. This is because such critics assume that, like Byron, they recognize the "primitive qualities" of Muslim society (Bagabas 1993, 182). While the lines on the Pasha are very critical of both him and his supposed Oriental personality, Blackstone remarks that the relatively rare praise of the Oriental, which can be found in some of the notes to the poem (McGann 1983, 209-10), actually reveals Byron's biased attitude in favour of the East, concluding that the poet is actually, "probing a love-relationship with Islam" (Blackstone 1974, 351).

This can mean that in recent years some aspects of the discourse towards the Orient have become more critical. Blackstone states Byron's contemporaries basically "saw his interest in Islam as eccentric, or, at best, picturesque" $(1974,325)$ They did not see any serious interest or 
personal inclination on Byron's behalf towards the Orient or Islam, while in the eyes of some recent critics, any lapse in criticism of the East seems to be a sign that the writer is turning Turk and reveals "the appeal Islam made to the young Byron" (Sharafuddin 1994, 227).

Numerous questions regarding the poet's representation of the Orient can also be raised, because of the numerous discrepancies in the poem and its footnotes. Sharafuddin, for example, points out, that throughout his works,

Byron recognizes the constraints imposed by the Turks on their women. This he does most explicitly in Childe Harold, Canto ii, stanza 61, where, describing the festivities following 'Ramazani's fast', in the gallery and courtyard of Ali Pasha's palace [...]. $(1994,244)$

Regardless of the fact that here again the critic does not realize that the people of this region, as well as Ali Pasha, are not Turkish (they are Albanian), the poet himself contradicts this general picture produced by himself and applauded by critics. Soon after Childe Harold passes Ali Pasha's "Haram's silent tower" $(2,496)$, he explains that:

Here woman's voice is never heard: apart, And scarce permitted, guarded, veil'd to move,

She yields to one her person and her heart, Tam'd to her cage, nor feels a wish to rove $(2,541-44)$.

These lines are in line with Sharafuddin's claim about the constraints on women. In Byron's poems women are neither seen nor heard, because they are basically held like animals in a cage. They are "Tam'd" and so they have no wish to taste freedom. These lines, however, contradict Byron's own footnotes to the poem:

The Albanians in general (I do not mean the cultivators of the earth in the provinces, who have also that appellation, but the mountaineers) have a fine cast of countenance; and the most beautiful women I ever beheld, in stature and in features $[\ldots]$ Their manner of walking is truly theatrical [...]. (McGann $1983,195)$

In the footnote to line 649 (canto 2) he also says:

[...] but the ladies (to whom the above is supposed to be addressed) have nothing under their little yellow boots and slippers but a well-turned and sometimes very white ankle. The Arnaout girls are much handsomer than the Greeks. (McGann 1983, 197)

The poem itself, along with the comments made by critics, does not correspond with its own footnotes. Byron speaks of the stature and features of Albanian women as well as their way of walking and even their "very white" ankles. However none of the critics ask, how the poet can describe the bodies of women "scarce permitted, guarded, veil'd to move" $(2,542)$ in such a detailed manner. 
These are not the only inconsistencies in the poem, however. One of the constant images that comes out of Byron's Orient throughout the tales is the "Unmov'd" and "stern" Muslim. Whereas in Canto 2 he speaks of what one critic sees as the frivolities that Orientals engage in after fasting during the day in Ramazan. (Bagabas 1993, 175)

After fasting, Bagabas claims, Muslims indulge in "immoral pleasures and amorous pursuits" (1993, 176). Byron, he continues, "is aware" of these facts about Muslims and therefore in the poem he implies that Muslims, "are anxious to throw off their cloak of piety and apparent devotion only to engage in acts of disobedience to Allah" $(1993,176)$. What is effectively being said is that all Muslims are by nature hypocritical. Even if the "Revel and feast" $(2,535)$ in Ali Pasha's court was linked to impiety, it is unclear how he or the poet could use this to generalize about the behaviour of all Easterners. This claim contradicts one of the few instances in the poem, where Byron speaks of Muslims in positive terms, and says in a footnote that they are most sincere in their "erroneous devotion" (McGann 1983, 311).

Ironically, in the same work Byron tells his readers that:

It is hazardous to say much on the subject of Turks and Turkey; since it is possible to live amongst them for twenty years without acquiring information, at least from themselves. (McGann 1983, 209)

This is an example of an Oriental representation where the Easterner is pictured as inscrutable and strange. However, it also negates the claim that Byron fully understands the Orient.

\section{CONCLUSIONS}

In our discussion of orientalist discourse in Lord Byron's Childe Harold's Pilgrimage we have tried to demonstrate that Byron's attitudes towards the 'Orient' in his poem are more or less stereotypical and often biased. We have argued that the poem's claim on the authenticity of the representations of the East is a subtle textual strategy despite the seemingly more favourable views towards 'Orientals' found in it, especially in the footnotes, compared to Turkish Tales. Our central contention is that similar discursive practices also seem to influence most of Byron's critics including contemporary scholars who have conducted numerous forms of textual analysis through differing theoretical approaches.

The claim of 'authenticity' of represention vis-a-vis the Orient, that Byron fully understands it, turns out to be highly questionable. This should be especially true for a person who has spent only a brief period in this land, does not even speak the language, and admits to his "slight experience" (McGann 1983, 209). In the poem, however, Byron like numerous contemporary critics generally comments as a specialist who understands even the most inner thoughts of the monolithic Turk or Albanian.

Of course, the poet's portrayal of the Orient is undoubtedly closely linked to his aspirations for Greece and is clearly not without bias. He wishes to "tear their name defil'd from Slavery's mournful page" $(2,719)$. Byron calls on them to remember how their ancestors defeated "Asia" $(2,852)$. It is interesting, however, that he shows no distaste at the thought of Greece becoming "an useful dependency" (McGann 1983, 202). This is even more significant 
if one accepts the claim that during this journey, "there is some evidence to suggest that when he moved further east he gathered information for the military" (Bone 2000, 5).

While what Sharafuddin $(1994,255)$ calls "Byron's diagnosis of the imperialism of Islam," rings clearly throughout his work, his critics are more or less silent about the role that Byron designates for English colonialism. Perhaps one should not be too surprised to see that, as Byron becomes more and more critical and hostile towards the Orient in his later works, these critics as well as numerous others continue to view his Oriental representations as more or less 'authentic.'

\section{References}

[1] Bagabas O. A. 1993. Byron's Representation of the Orient in Childe Harold's Pilgrimage, Don Juan, and the Oriental Tales (PhD Diss.). Essex University.

[2] Blackstone B., Journal of European Studies 4 (4) (1974) 325-631.

[3] Bone, D. 2000. Byron. Tavistock: Northcote House.

[4] McGann, J. 1980-1993. Byron, George Gordon, Baron. The Complete Poetical Works. 7 vols. Oxford: Clarendon Press.

[5] Cardwell, R. A. 2006. Byron and the Orient: Appropriation or speculation? In Cochran, P. (ED). Byron and orientalism (pp. 152-172). Newcastle: Cambridge Scholars Press.

[6] Edinburgh Review 21:42 (1813: July, 308).

[7] Fleming, A. 2006. Byron the maker. London: The Book Guild.

[8] Fleming, K. E. 1999. The Muslim Bonaparte: Diplomacy and orientalism in Ali Pasha's Greece. Princeton, New Jersey: Princeton University Press.

[9] Franklin, C. 2000. Byron: A literary life. London: Macmillan.

[10] Gleckner, R. F. 1967. Byron and the ruins of paradise. Baltimore: Johns Hopkins Press.

[11] Joseph, M. K. 1964. Byron the poet. London: Victor Gollancz.

[12] Loomba, A. 1998. Colonialism/Postcolonialism. London: Routledge.

[13] Lopez-Baralt, L. 1997. Islam in Spanish literature: From the Middle Ages to the present, San Juan: Brill.

[14] Marchand, L. A. Childe Harold, cantos 1-2 (1965). In Jump, J. (ED). Childe Harold's Pilgrimage and Don Juan (pp. 215-237). London: Macmillan.

[15] Marchand, L. A. (Ed). 1974. Byron's letters and journals. 5 Vol. London: John Murray.

[16] McGann, J. 1983. The romantic ideology: A critical investigation. Chicago: University of Chicago Press.

[17] Mole, T. 2007. Byron's romantic celebrity: Industrial culture and the hermeneutic of intimacy. Houndmills and New York: Palgrave Macmillan. 
[18] Oueijan, N. B. 1999. A compendium of Eastern elements in Byron's Oriental Tales. New York: Peter Lang.

[19] Prothero, R. E. 1973. Centenary reflections on Childe Harold's Pilgrimage and Don Juan (1924). In Jump, J. (ED). Childe Harold's Pilgrimage and Don Juan. London: Macmillan

[20] Rutherford, An. 1961. Byron: A critical study. Edinburgh: Oliver and Boyd.

[21] Rutherford, A. (Ed). 1970. Byron: the Critical Heritage. London: Routledge.

[22] Said, E. 1980. Orientalism. Harmondsworth: Penguin.

[23] Sharafuddin, M. 1994. Islam and romantic orientalism. London: I.B. Tauris Publishers.

[24] Walker, K. 1979. Byron's readers: A study of attitudes towards Byron 1812-1832. Salzburg: University of Salzburg.

[25] Wiener, Harold. 1938. The Eastern background of Byron' Oriental Tales. Dissertation. Yale University. 